\title{
Exercise Plus Presleep Protein Ingestion Increases Overnight Muscle Connective Tissue Protein Synthesis Rates in Healthy Older Men
}

\author{
Andrew M. Holwerda, \\ Jorn Trommelen, and Imre W.K. Kouw \\ Maastricht University Medical Centre+ and \\ Top Institute Food and Nutrition (TIFN)
}

\author{
Joan M. Senden, Joy P.B. Goessens, \\ Janneau van Kranenburg, and Annemie P. Gijsen \\ Maastricht University Medical Centre+
}

\author{
Lex B. Verdijk and Luc J.C. van Loon \\ Maastricht University Medical Centre+ and \\ Top Institute Food and Nutrition (TIFN)
}

\begin{abstract}
Protein ingestion and exercise stimulate myofibrillar protein synthesis rates. When combined, exercise further increases the postprandial rise in myofibrillar protein synthesis rates. It remains unclear whether protein ingestion with or without exercise also stimulates muscle connective tissue protein synthesis rates. The authors assessed the impact of presleep protein ingestion on overnight muscle connective tissue protein synthesis rates at rest and during recovery from resistance-type exercise in older men. Thirty-six healthy, older men were randomly assigned to ingest $40 \mathrm{~g}$ intrinsically $\mathrm{L}-\left[1-{ }^{13} \mathrm{C}\right]$-phenylalanine and $\mathrm{L}-\left[1-{ }^{13} \mathrm{C}\right]-$ leucinelabeled casein protein (PRO, $n=12$ ) or a nonprotein placebo (PLA, $n=12$ ) before going to sleep. A third group performed a single bout of resistance-type exercise in the evening before ingesting $40 \mathrm{~g}$ intrinsically-labeled casein protein prior to sleep $(\mathrm{EX}+\mathrm{PRO}, n=12)$. Continuous intravenous infusions of $\mathrm{L}-\left[\right.$ ring $\left.^{2}{ }^{2} \mathrm{H}_{5}\right]$-phenylalanine and $\mathrm{L}-\left[1-{ }^{13} \mathrm{C}\right]-$ leucine were applied with blood and muscle tissue samples collected throughout overnight sleep. Presleep protein ingestion did not increase muscle connective tissue protein synthesis rates $(0.049 \pm 0.013$ vs. $0.060 \pm 0.024 \% / \mathrm{hr}$ in PLA and PRO, respectively; $p=.73)$. Exercise plus protein ingestion resulted in greater overnight muscle connective tissue protein synthesis rates $(0.095 \pm 0.022 \% / \mathrm{hr})$ when compared with PLA and PRO $(p<.01)$. Exercise increased the incorporation of dietary protein-derived amino acids into muscle connective tissue protein $(0.036 \pm 0.013$ vs. $0.054 \pm 0.009$ mole percent excess in PRO vs. EX+PRO, respectively; $p<.01)$. In conclusion, resistance-type exercise plus presleep protein ingestion increases overnight muscle connective tissue protein synthesis rates in older men. Exercise enhances the utilization of dietary protein-derived amino acids as precursors for de novo muscle connective tissue protein synthesis during overnight sleep.
\end{abstract}

Keywords: aging, collagen, injury

The age-related decline in skeletal muscle mass and strength, termed sarcopenia, results in impairments in functional capacity (Baumgartner et al., 1998; Mitchell et al., 2012). Aging is associated with the maladaptation of muscle collagenous tissue (i.e., connective tissue), which transfers force from contracting muscle tissue to tendons and bones (Alnaqeeb et al., 1984; Babraj et al., 2005; Haus et al., 2007; Ramaswamy et al., 2011). Poor-quality muscle connective tissue impairs lateral force transmission (Ramaswamy et al., 2011; Zhang \& Gao, 2014) and increases muscle stiffness (Wood et al., 2014), which contribute to the age-related decline in muscle strength and functional capacity (Azizi et al., 2017; Kragstrup et al., 2011).

Skeletal muscle tissue (mal)adaptation is regulated by the net balance between muscle protein synthesis and breakdown rates,

The authors are with the NUTRIM School of Nutrition and Translational Research in Metabolism, Maastricht University Medical Centre+, Maastricht, The Netherlands. Holwerda, Trommelen, Kouw, Verdijk, and van Loon are also with the Top Institute Food and Nutrition (TIFN), Wageningen, The Netherlands. van Loon (L.vanLoon@maastrichtuniversity.nl) is corresponding author. with a tissue turnover rate of 1-2\% per day (Koopman \& van Loon, 2009). Food ingestion and physical activity are two major stimuli that increase muscle protein synthesis rates (Trommelen et al., 2019). Protein ingestion increases plasma essential amino acid (leucine) availability, which increases muscle protein synthesis rates (Volpi et al., 2003). Resistance-type exercise increases muscle protein synthesis rates and sensitizes skeletal muscle tissue to the anabolic properties of protein ingestion (Pennings et al., 2011b).

The impact of food ingestion and physical activity on muscle connective tissue protein synthesis rates has not yet been fully elucidated, especially in the older population. Exercise increases muscle connective tissue protein synthesis rates in both younger and older individuals (Cuthbertson et al., 2006; Dideriksen et al., 2016; Holm et al., 2010; Mikkelsen et al., 2015; Moore et al., 2005; Trommelen et al., 2020). However, nearly all of the existing studies have shown no impact of protein ingestion on muscle connective tissue protein synthesis rates at rest or during postexercise recovery (Babraj et al., 2005; Dideriksen et al., 2016, 2011; Holm et al., 2010; Mikkelsen et al., 2015). The absence of a detectable impact of protein ingestion on muscle connective tissue protein synthesis 
rates at rest or during postexercise recovery may be related to the duration of the postprandial assessment periods in the previous studies. Notably, Holm et al. (2017) recently demonstrated that the ingestion of $\sim 18 \mathrm{~g}$ whey protein further increased postexercise muscle connective tissue protein synthesis rates when compared with the ingestion of carbohydrate during the late postprandial period (i.e., between 3 and $5 \mathrm{hr}$ after protein ingestion). These findings suggest that protein ingestion may have a delayed impact ( $>3 \mathrm{hr}$ ) on stimulating muscle connective tissue protein synthesis rates at rest and during postexercise recovery. Our research group has demonstrated that presleep casein protein ingestion and resistance-type exercise increase myofibrillar protein synthesis during overnight sleep in both younger and older individuals (Holwerda et al., 2016; Kouw et al., 2017; Snijders et al., 2019; Trommelen et al., 2016, 2018). Therefore, overnight sleep represents a more prolonged postprandial period $(\sim 8 \mathrm{hr})$, which may be better suited to evaluate the (potentially delayed) impact of protein ingestion on muscle connective tissue protein synthesis rates.

Casein is rich in leucine and is slowly digested (Pennings et al., 2011a). Therefore, casein may be a preferred protein source to stimulate connective tissue protein synthesis during overnight sleep (Holwerda et al., 2016; Kouw et al., 2017; Snijders et al., 2019; Trommelen et al., 2016, 2018). We have recently shown that presleep ingestion of $30 \mathrm{~g}$ casein does not stimulate overnight connective tissue protein synthesis rates during postexercise recovery in young men. Here, we hypothesized that a larger, $40 \mathrm{~g}$ dose of casein ingested before sleep may increase muscle connective tissue protein synthesis rates at rest and that dietary protein-derived amino acids may be utilized as precursors for de novo muscle connective tissue protein synthesis during overnight sleep in healthy, older men. Furthermore, we hypothesized that a bout of resistance-type exercise combined with $40 \mathrm{~g}$ casein protein ingestion would further increase overnight muscle connective tissue protein synthesis rates and the utilization of dietary protein-derived amino acids for de novo muscle connective tissue protein synthesis.

\section{Methods}

\section{Subjects}

A total of 36 healthy, normoglycemic, older men ( $70 \pm 5$ years) were selected to participate in the present study. Subjects' characteristics are presented in Table 1. Subjects were randomly assigned to ingest $40 \mathrm{~g}$ intrinsically $\mathrm{L}-\left[1-{ }^{13} \mathrm{C}\right]$-phenylalanine and $\mathrm{L}-\left[1-{ }^{13} \mathrm{C}\right]$-leucine-labeled casein protein (PRO and EX+PRO, both $n=12$ ) or a nonprotein placebo (PLA, $n=12$ ) before going to sleep. One group performed a single bout of resistance-type exercise earlier that evening prior to ingesting the $40 \mathrm{~g}$ intrinsically-labeled protein $(\mathrm{EX}+\mathrm{PRO}, n=12)$. All subjects were informed of the nature and possible risks of the experimental procedures before their written informed consent was obtained. Randomization was computer generated, and all procedures and analysis were performed in a double-blind manner. The trial was conducted between April 2013 and October 2013 at Maastricht University Medical Centre, Maastricht, The Netherlands. This study is part of a greater project investigating the impact of exercise and presleep protein ingestion on overnight muscle protein synthesis, parts of which have already been published (Holwerda et al., 2016; Kouw et al., 2017). Muscle connective tissue protein analyses could only be conducted in $n=10$ for PLA, $n=7$ for PRO, and $n=9$ for EX+PRO treatments due to an insufficient amount of muscle tissue left. The study was approved by the Medical Ethical Committee of the Maastricht University Medical Centre, The Netherlands, and conformed to standards for the use of human subjects in research as outlined in the most recent version of the Helsinki Declaration. The study was registered at Netherlands Trial Register as NTR3885.

\section{Pretesting}

Participants arrived at the laboratory at $8: 30$ a.m. by car or public transport in an overnight fasted state. Upon arrival, body weight, body composition, and bone mineral content were measured with

Table 1 Subjects' Characteristics

\begin{tabular}{|c|c|c|c|c|}
\hline Variable & $\operatorname{PLA}(n=10)$ & PRO $(n=7)$ & EX+PRO $(n=9)$ & $p$ value \\
\hline Age (years) & $71 \pm 6$ & $69 \pm 4$ & $70 \pm 5$ & .63 \\
\hline Total body mass (kg) & $74.7 \pm 9.6$ & $78.4 \pm 8.6$ & $81.4 \pm 5.8$ & .22 \\
\hline Total lean mass $(\mathrm{kg})$ & $57.8 \pm 7.6$ & $60.3 \pm 5.5$ & $61.4 \pm 5.5$ & .46 \\
\hline Appendicular lean mass $(\mathrm{kg})$ & $25.1 \pm 3.8$ & $25.9 \pm 2.8$ & $26.5 \pm 3.0$ & .66 \\
\hline Body fat $(\%)$ & $19.3 \pm 2.1$ & $20.0 \pm 3.2$ & $21.8 \pm 4.5$ & .27 \\
\hline Height (m) & $1.77 \pm 0.09$ & $1.77 \pm 0.07$ & $1.75 \pm 0.05$ & .86 \\
\hline BMI $\left(\mathrm{kg} / \mathrm{m}^{2}\right)$ & $23.8 \pm 1.6$ & $24.9 \pm 2.2$ & $26.5 \pm 2.3^{*}$ & .03 \\
\hline Systolic BP (mmHg) & $153 \pm 13$ & $140 \pm 18$ & $148 \pm 13$ & .25 \\
\hline Diastolic BP (mmHg) & $76 \pm 10$ & $78 \pm 9$ & $74 \pm 6$ & .76 \\
\hline Resting HR (bpm) & $57 \pm 7$ & $61 \pm 7$ & $60 \pm 11$ & .74 \\
\hline $\mathrm{HbA}_{1 \mathrm{c}}(\%)$ & $5.5 \pm 0.5$ & $5.3 \pm 0.6$ & $5.4 \pm 0.3$ & .66 \\
\hline Fasted glucose $(\mathrm{mmol} / \mathrm{L})$ & $5.1 \pm 0.6$ & $5.3 \pm 0.6$ & $6.0 \pm 1.1$ & .08 \\
\hline 1RM-leg press $(\mathrm{kg})$ & - & - & $165 \pm 26$ & - \\
\hline 1RM-leg extension $(\mathrm{kg})$ & - & - & $75 \pm 17$ & - \\
\hline
\end{tabular}

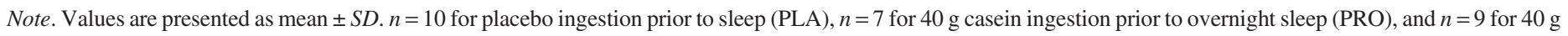

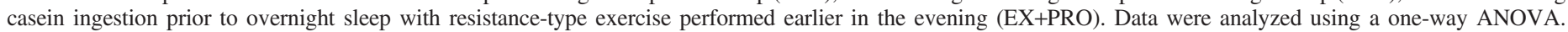

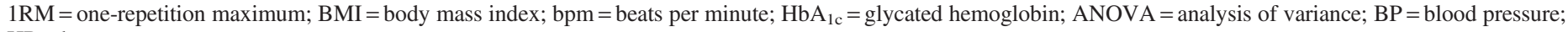
$\mathrm{HR}=$ heart rate.

*Significantly different $(p<.05)$ from PLA. 
DEXA (dual-energy X-ray absorptiometry, Discovery A; Hologic, Bedford, MA). Thereafter, all participants performed an oral glucose tolerance test. Plasma glucose and insulin concentrations were measured to determine oral glucose intolerance and/or the presence of Type 2 diabetes according to 2006 American Diabetes Association guidelines (American Diabetes Association, 2004). All subjects were screened on medical issues and excluded if any gastrointestinal, neurological, or renal diseases were present.

Subjects randomized into the EX+PRO group were cleared to perform physical activity by a cardiologist who examined electrocardiograms obtained at rest and during submaximal cycling (performed at $70 \%$ of age-predicted heart rate max). The subjects were then familiarized with the exercise equipment and physical activity protocol. Subjects first performed a 10-min cycling warm-up at 70\% of their age-predicted heart rate maximum before completing an estimation of their 1RM (one-repetition maximum) on the leg press and leg extension exercises using the multiple repetitions testing procedure (Mayhew et al., 1995). For each exercise, subjects performed 10 submaximal, or warm-up, repetitions to become familiarized with the equipment and to have lifting technique critiqued and corrected. Subjects then performed sets at progressively increasing loads until failing to complete a valid repetition, judged by their inability to complete the full range of motion for an exercise. Ideally, subjects failed within 3-6 repetitions during the last and heaviest set. A 2-min resting period between subsequent attempts was allowed. The pretesting and experimental trials were separated by a period of at least 7 days.

\section{Diet and Physical Activity}

All volunteers were instructed to refrain from any exhaustive physical activity and to keep their diet as consistent as possible $48 \mathrm{hr}$ prior to the trial. On the day of the experiment, a standardized diet (three meals and two snacks) was consumed which provided $9.3 \pm 0.6 \mathrm{MJ}$, with $55 \pm 2$ energy $\%$ (En\%) provided as carbohydrate, $27 \pm 2 \mathrm{En} \%$ as fat, and $16 \pm 0.2 \mathrm{En} \%$ as protein. The energy content of the standardized diet was based upon individual energy requirements calculated using the Harris-Benedict equation and adjusted using a physical activity factor of 1.4 to ensure ample energy intake. Dietary protein intake averaged $1.1 \pm 0.01 \mathrm{~g} / \mathrm{kg}$ bodyweight, with $35 \pm 1 \%$ of the protein consumed at dinner.

\section{Experimental Protocol}

A schematic representation of the study protocol is displayed in Figure 1. At 5:30 p.m., participants reported to the lab and had Teflon catheters inserted into the antecubital veins of each arm. At 6:30 p.m. $(t=-300 \mathrm{~min})$, all subjects consumed the same standardized dinner meal under supervision $(2.5 \pm 0.1 \mathrm{MJ}$, providing $62 \pm 0.2 \mathrm{En} \%$ carbohydrate, $19 \pm 0.1 \mathrm{En} \%$ fat, and $19 \pm 0.1 \mathrm{En} \%$ protein). Subjects in the $\mathrm{EX}+\mathrm{PRO}$ group performed a single physical activity session between 7:45 p.m. and 8:45 p.m. After the physical activity session, at 9:00 p.m. ( $t=-150 \mathrm{~min})$, a background blood sample was taken prior to the initiation of the tracer infusion protocol. The plasma and muscle phenylalanine, tyrosine, and leucine pools were primed with a single intravenous dose (priming dose) of L-[ring- $\left.{ }^{2} \mathrm{H}_{5}\right]$-phenylalanine $\left(2.0 \mu \mathrm{mol} \cdot \mathrm{kg}^{-1}\right), \quad \mathrm{L}-\left[\right.$ ring $\left._{-}{ }^{2} \mathrm{H}_{2}\right]$-tyrosine $\left(0.615 \mu \mathrm{mol} \cdot \mathrm{kg}^{-1}\right)$, and $\mathrm{L}-\left[1-{ }^{13} \mathrm{C}\right]$-leucine $\left(4.0 \mu \mathrm{mol} \cdot \mathrm{kg}^{-1}\right)$. Once primed, the continuous stable isotope infusion was initiated (infusion rate: $0.05 \mu \mathrm{mol} \cdot \mathrm{kg}^{-1} \cdot \mathrm{min}^{-1}$ $\mathrm{L}-\left[\right.$ ring- $\left.{ }^{2} \mathrm{H}_{5}\right]$-phenylalanine, $0.015 \mu \mathrm{mol} \cdot \mathrm{kg}^{-1} \cdot \mathrm{min}^{-1} \mathrm{~L}-\left[\right.$ ring $\left._{-}{ }^{2} \mathrm{H}_{2}\right]-$ tyrosine, $0.1 \mu \mathrm{mol} \cdot \mathrm{kg}^{-1} \cdot \mathrm{min}^{-1} \mathrm{~L}-\left[1-{ }^{13} \mathrm{C}\right]$-leucine; Cambridge Isotope Laboratories, Andover, MA). Participants rested for $2.5 \mathrm{hr}$ until 11:30 p.m. ( $t=0 \mathrm{~min})$, when the first muscle biopsy sample was taken. Subsequently, subjects ingested a $450-\mathrm{ml}$ beverage containing either only water $\left(0 \mathrm{~g}\right.$ protein, PLA) or $40 \mathrm{~g}$ intrinsically $\mathrm{L}-\left[1-{ }^{13} \mathrm{C}\right]-$ phenylalanine and $\mathrm{L}-\left[1-{ }^{13} \mathrm{C}\right]$-leucine-labeled casein (PRO and EX +PRO), and $1.5 \mathrm{ml}$ of vanilla extract added to improve palatability (Dr. Oetker, Amersfoort, The Netherlands), within 5 min. The amino acid composition of the $40 \mathrm{~g}$ casein protein is displayed in Supplemental Table 1 (available online). The casein did not contain any carbohydrates. Subjects went to sleep at 12:00 a.m. During the night, blood samples $(10 \mathrm{ml})$ were taken without waking up the subjects at $t=0,30,60,90,150,210,330$, and $450 \mathrm{~min}$ relative to the intake of the protein drink. A second muscle biopsy was obtained from the contralateral leg 7.5 hr later at 7:00 a.m. ( $t=450 \mathrm{~min})$.

Blood samples were collected in ethylenediaminetetraacetic acid (EDTA) containing tubes and centrifuged at $1,000 \mathrm{~g}$ for $10 \mathrm{~min}$ at $4{ }^{\circ} \mathrm{C}$. Aliquots of plasma were frozen in liquid nitrogen and stored at $-80^{\circ} \mathrm{C}$. Muscle biopsies were obtained from the middle region of the $M$. vastus lateralis, $15 \mathrm{~cm}$ above the patella and approximately $4 \mathrm{~cm}$ below entry through the fascia, using the percutaneous needle biopsy technique (Bergström \& Hultman, 1967). Muscle samples were dissected carefully and freed from

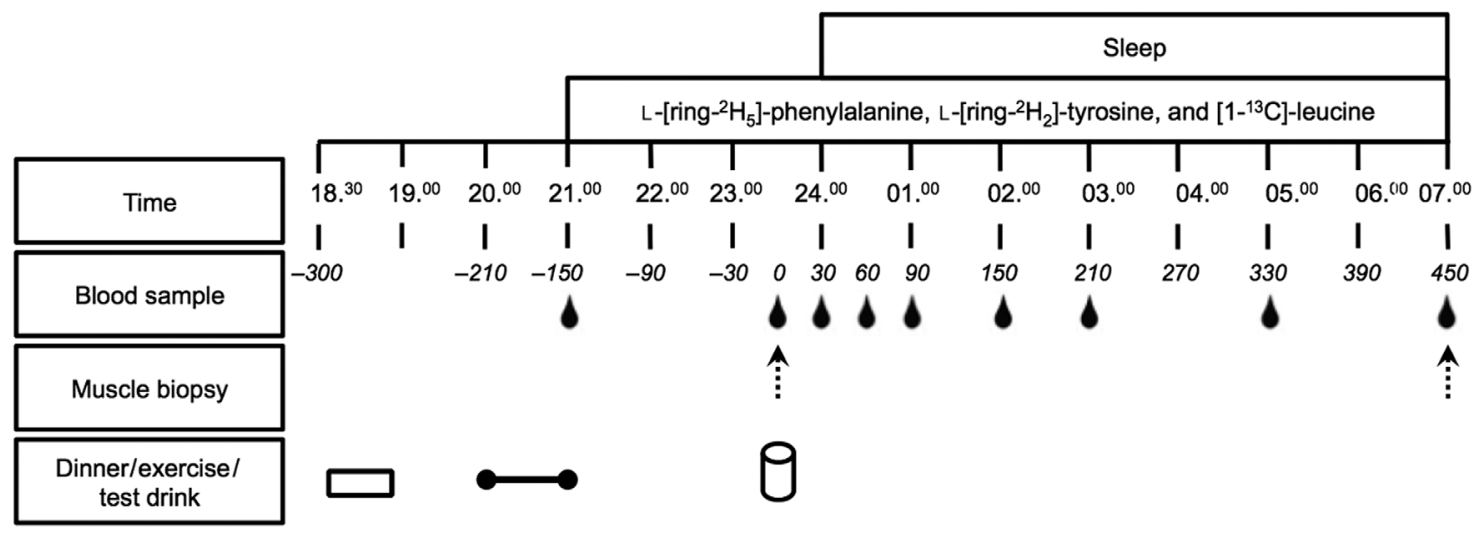

Figure 1 - Experimental protocol. A total of 36 healthy, normoglycemic, older men were randomly assigned to ingest $40 \mathrm{~g}$ intrinsically L-[1- $\left.{ }^{13} \mathrm{C}\right]-$ phenylalanine and $\mathrm{L}-\left[1-{ }^{13} \mathrm{C}\right]$-leucine-labeled casein protein (PRO and EX+PRO) or a nonprotein placebo (PLA) before going to sleep. One group performed a single bout of resistance-type exercise earlier that evening prior to ingesting the $40 \mathrm{~g}$ intrinsically-labeled protein (EX+PRO). Subjects underwent an intravenous infusion of stable isotope amino acid tracers, and skeletal muscle biopsies were collected before and after sleep to assess muscle connective tissue protein synthesis rates. 
any visible nonmuscle material. The muscle samples were immediately frozen in liquid nitrogen and stored at $-80{ }^{\circ} \mathrm{C}$ until further analysis.

\section{Physical Activity Protocol}

The physical activity protocol consisted of 60 min of moderateintensity lower-body resistance-type exercise. After $15 \mathrm{~min}$ of selfpaced cycling at $100 \mathrm{~W}$ with a cadence of $60-80 \mathrm{rpm}$, subjects performed six sets of 10 repetitions on the horizontal leg press machine (Technogym BV, Rotterdam, The Netherlands) and six sets of 10 repetitions on the leg extension machine (Technogym $\mathrm{BV})$. The first two sets of both exercises were performed at 55\% and $65 \% 1 \mathrm{RM}$, respectively, and Sets 3-6 were performed at 75\% 1RM. Subjects were allowed to rest for 2 min between all sets.

\section{Production of Intrinsically Labeled Protein and Tracer Preparation}

Details on the production of intrinsically L- $\left[1-{ }^{13} \mathrm{C}\right]$-phenylalanine and $\mathrm{L}-\left[1-{ }^{13} \mathrm{C}\right]$-leucine-labeled casein protein and preparation of $\mathrm{L}-\left[\right.$ ring- $\left.{ }^{2} \mathrm{H}_{5}\right]$-phenylalanine, L- $\left[1-{ }^{13} \mathrm{C}\right]$-leucine, and L- $\left[\operatorname{ring}_{-}{ }^{2} \mathrm{H}_{2}\right]-$ tyrosine tracers have been described previously (Holwerda et al., 2016).

\section{Plasma and Muscle Connective Tissue Protein Analyses}

Details on the measurement of plasma glucose, insulin, and free $\mathrm{L}-\left[\right.$ ring- $\left.{ }^{2} \mathrm{H}_{5}\right]$-phenylalanine, L- $\left[1-{ }^{13} \mathrm{C}\right]$-phenylalanine, and L- $\left[1-{ }^{13} \mathrm{C}\right]-$ leucine enrichments have been described previously (Holwerda et al., 2016). Muscle connective tissue protein-enriched fractions were isolated from $\sim 60 \mathrm{mg}$ of wet muscle tissue by hand homogenizing on ice using a pestle in a standard extraction buffer $(10 \mu \mathrm{l} / \mathrm{mg})$. The samples were spun for $15 \mathrm{~min}$ at $800 \mathrm{~g}$ and $4{ }^{\circ} \mathrm{C}$. The pellet was washed with $400 \mu \mathrm{l}$ of extraction buffer before vortexing and centrifugation at $800 \mathrm{~g}$ and $4{ }^{\circ} \mathrm{C}$ for $10 \mathrm{~min}$. The supernatant was

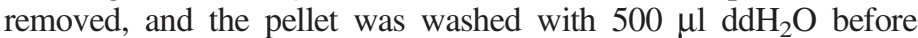
vortexing and centrifugation at $800 \mathrm{~g}$ and $4{ }^{\circ} \mathrm{C}$ for $10 \mathrm{~min}$. The supernatant was removed, and $1 \mathrm{ml}$ of homogenization buffer was added and the material was suspended by vortexing prior to transferring into microtubes containing $1.4 \mathrm{~mm}$ ceramic beads and Lysing Matrix D (MP Biomedicals, Irvine, CA). The microtubes were vigorously shaken four times for $45 \mathrm{~s}$ at $5.5 \mathrm{~m} / \mathrm{s}$ (FastPrep-24 5G, MP Biomedicals, Irvine, CA) to mechanically lyse the protein network. Samples were then left to rest at $4{ }^{\circ} \mathrm{C}$ for $3 \mathrm{hr}$ before centrifugation at $800 \mathrm{~g}$ and $4{ }^{\circ} \mathrm{C}$ for $20 \mathrm{~min}$, discarding the supernatant and adding $1 \mathrm{ml}$ of homogenization buffer. The microtubes were shaken for $45 \mathrm{~s}$ at $5.5 \mathrm{~m} / \mathrm{s}$ before centrifugation at $800 \mathrm{~g}$ and $4{ }^{\circ} \mathrm{C}$ for $20 \mathrm{~min}$. The supernatant was discarded and $1.5 \mathrm{ml}$ of $\mathrm{KCl}$ buffer was added to dissolve connective tissue proteins overnight at $4{ }^{\circ} \mathrm{C}$. The next morning, samples were vortexed and centrifuged at $1,600 \mathrm{~g}$ for 20 min at $4{ }^{\circ} \mathrm{C}$. The supernatant was removed, and the pellet was mixed with $1-\mathrm{ml} \mathrm{KCl}$ buffer and left for $2 \mathrm{hr}$ at $4{ }^{\circ} \mathrm{C}$. The samples were vortexed, centrifuged at $1,600 \mathrm{~g}$ for $20 \mathrm{~min}$ at $4{ }^{\circ} \mathrm{C}$, and the supernatant was discarded. This protocol results in approximately $65 \%$ recovery of total muscle tissue collagen and contains both immature and mature connective tissue proteins. The remaining pellet was suspended in $1 \mathrm{ml}$ of $6 \mathrm{M} \mathrm{HCl}$ in glass screw-cap tubes and left to hydrolyze overnight at $110{ }^{\circ} \mathrm{C}$. The free amino acids from the hydrolyzed connective protein pellet were dried under a nitrogen stream while being heated to $120^{\circ} \mathrm{C}$. The free amino acids were then purified and converted into their N-ethoxycarbonyl ethyl ester derivatives prior to measurement of enrichment on the GC-C-IRMS, as has been described previously (Holwerda et al., 2016).

\section{Calculations}

The fractional synthetic rate (FSR) of muscle connective tissue protein was calculated by dividing the increment in muscle connective tissue protein enrichment by the respective precursor amino acid tracer enrichments. Consequently, muscle connective tissue protein FSR was calculated as follows:

$$
\operatorname{FSR}(\% / \mathrm{hr})=\left(\frac{\mathrm{E}_{\mathrm{m} 2}-\mathrm{E}_{\mathrm{m} 1}}{\mathrm{E}_{\text {precursor }} \times t}\right) \times 100 \%
$$

$\mathrm{E}_{\mathrm{m} 1}$ and $\mathrm{E}_{\mathrm{m} 2}$ represent muscle connective tissue protein-bound $\mathrm{L}-\left[\right.$ ring- $\left.{ }^{2} \mathrm{H}_{5}\right]$-phenylalanine or $\mathrm{L}-\left[1-{ }^{13} \mathrm{C}\right]$-leucine enrichments at $t=0 \mathrm{~min}$ and $450 \mathrm{~min}$, respectively. $\mathrm{E}_{\text {precursor }}$ represents the average plasma free $\mathrm{L}-\left[\right.$ ring- $\left.{ }_{-}^{2} \mathrm{H}_{5}\right]$-phenylalanine or $\mathrm{L}-\left[1-{ }^{13} \mathrm{C}\right]$-leucine enrichment during the tracer incorporation period, and $t$ indicates the time interval (in hours) between biopsies.

\section{Statistics}

All data in text are expressed as mean $\pm S D$. Baseline characteristics between groups were compared using a one-way analysis of variance. Time-dependent variables (i.e., plasma glucose, insulin, amino acid concentrations, and tracer enrichments) were analyzed by a twofactor repeated-measures analysis of variance with time as a withinsubjects factor and treatment group as a between-subjects factor. The analysis was carried out for the period starting at the time of protein or placebo ingestion $(t=0 \mathrm{~min})$ until the end of the experimental trial $(t=450 \mathrm{~min})$. Non-time-dependent variables (i.e., muscle connective tissue protein FSR and $\mathrm{L}-\left[1-{ }^{13} \mathrm{C}\right]$-phenylalanine enrichment) were compared between treatment groups using a one-way analysis of variance. Upon a significant finding, Bonferroni-corrected post hoc comparisons were performed to identify differences. Statistical significance was set at $p<.05$. All calculations were performed using SPSS (version 24.0; SPSS Inc., Chicago, IL).

\section{Results}

\section{Plasma Glucose and Insulin Concentrations}

Plasma glucose concentrations (Supplemental Figure 1A) were lower during the overnight period in the PLA treatment when compared with the PRO and EX+PRO treatments (treatment effect: $p<.01$, data not shown). Plasma insulin concentrations (Supplemental Figure 1B) increased rapidly after protein ingestion (PRO and EX+PRO) in comparison with PLA (Time $\times$ Treatment interaction, $p<.01$, data not shown). Peak plasma insulin concentrations were higher in PRO and $\mathrm{EX}+\mathrm{PRO}$ in comparison with PLA (both $p<.05$ ), with no differences detected between PRO and $\mathrm{EX}+\mathrm{PRO}(p=.99)$.

\section{Plasma Amino Acid Concentrations and Enrichments}

Plasma leucine (Figure 2a) concentrations increased in PRO and $\mathrm{EX}+\mathrm{PRO}$ and were elevated throughout the night in comparison with PLA (Time $\times$ Treatment interaction, $p<.01$ ). No differences in plasma leucine concentrations were detected between PRO and $\mathrm{EX}+\mathrm{PRO}(p>.05$ at all time points). Plasma phenylalanine 

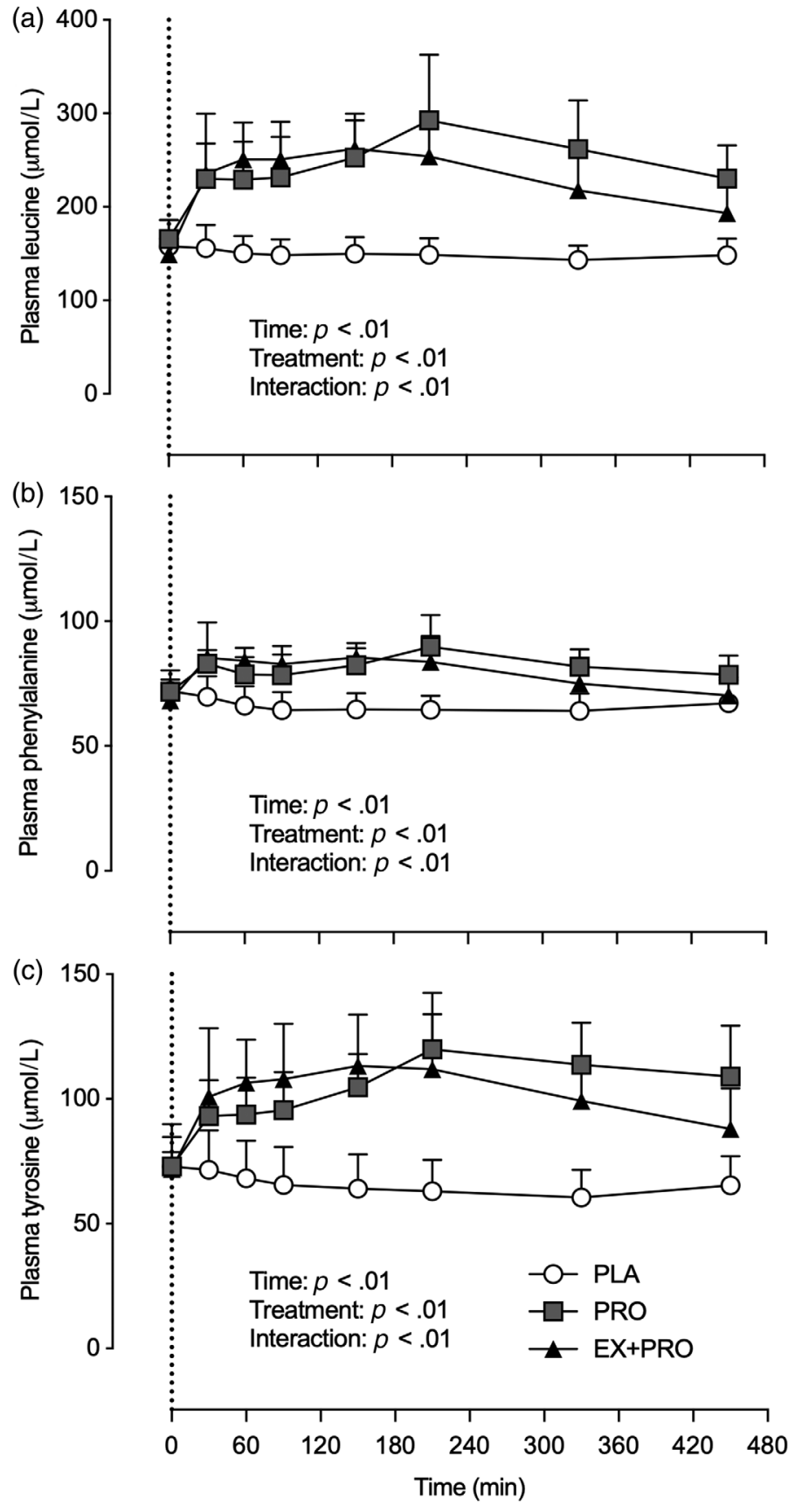

Figure 2 - (a) Overnight plasma leucine, (b) phenylalanine, and (c) tyrosine concentrations $(\mu \mathrm{mol} / \mathrm{L})$. The dotted line represents the ingestion of the presleep protein. Plasma concentrations over time are expressed as mean $\pm S D$. Plasma concentrations over time were analyzed with a two-way repeated measures (within-subject factor: time, betweensubject factor: treatment) ANOVA. Leucine concentrations: time effect, $p<.01$; treatment effect, $p<.01$; Time $\times$ Treatment interaction, $p<.01$. Phenylalanine concentrations: time effect, $p<.01$; treatment effect, $p<.01$; Time $\times$ Treatment effect: $p<.01$. Tyrosine concentrations: time effect: $p<.01$; treatment effect: $p<.01$; Time $\times$ Treatment effect: $p<.01$. PLA $=$ presleep placebo ( $0 \mathrm{~g}$ protein $)$ ingestion without prior exercise; $\mathrm{PRO}=$ presleep protein $(40 \mathrm{~g}$ casein $)$ ingestion without prior exercise; EX $+\mathrm{PRO}=$ presleep protein $(40 \mathrm{~g}$ casein $)$ ingestion with prior resistance-type exercise; ANOVA = analysis of variance.
(Figure 2b) concentrations increased in PRO and EX+PRO and were elevated throughout the night in comparison with PLA (Time $\times$ Treatment interaction, $p<.01$ ). No differences in plasma phenylalanine concentrations were detected between PRO and EX + PRO ( $p>.05$ at all time points). Plasma tyrosine (Figure 2c) concentrations increased in PRO and EX+PRO and were elevated throughout the night in comparison with PLA (Time $\times$ Treatment interaction, $p<.01)$. No differences in plasma tyrosine concentrations were detected between $\mathrm{PRO}$ and $\mathrm{EX}+\mathrm{PRO}(p>.05$ at all time points).

Plasma L- $\left[\right.$ ring $\left._{-}{ }^{2} \mathrm{H}_{5}\right]$-phenylalanine (Figure 3a), L- $\left[1-{ }^{13} \mathrm{C}\right]-$ leucine (Figure $3 \mathrm{~b}$ ), and $\mathrm{L}-\left[1-{ }^{13} \mathrm{C}\right]$-phenylalanine (Figure $3 \mathrm{c}$ ) enrichments did not differ between treatments prior to drink ingestion $\left(t=0\right.$ min, $p>.05$ ). Plasma L- $\left[r i n g-{ }_{-}^{2} \mathrm{H}_{5}\right]$-phenylalanine enrichments decreased slightly in PRO and EX+PRO and were lower throughout the night in comparison with PLA (Time $\times$ Treatment interaction, $p<.01)$. No differences in plasma L- $\left[\right.$ ring $\left._{-}{ }^{2} \mathrm{H}_{5}\right]$-phenylalanine enrichments were detected between PRO and EX+PRO $(p>.05$ at all time points). Plasma $\mathrm{L}-\left[1-{ }^{13} \mathrm{C}\right]$-leucine enrichments increased slightly following protein ingestion (Time $\times$ Treatment interaction, $p<.05$ ) and were higher in EX+PRO versus PLA at $t=30,60$, and 150 min $($ all $p<.05)$. Plasma L- $\left[1-{ }^{13} \mathrm{C}\right]$-phenylalanine enrichments increased in PRO and $\mathrm{EX}+\mathrm{PRO}$ only (Time $\times$ Treatment interaction, $p<.01)$. No differences in plasma L- $\left[1-{ }^{13} \mathrm{C}\right]$-phenylalanine enrichments were detected between PRO and $\mathrm{EX}+\mathrm{PRO}(p>.05$ at all time points).

\section{Muscle Connective Tissue Protein FSR and Protein- Bound Enrichments}

Overnight muscle connective tissue protein FSR based on the infused $\mathrm{L}-\left[\right.$ ring- ${ }^{2} \mathrm{H}_{5}$-phenylalanine tracer (Figure 4a) were higher in EX+PRO $\left(0.095 \pm 0.022 \% \cdot \mathrm{hr}^{-1}, n=9\right)$ when compared with PRO $(0.060 \pm$ $\left.0.024 \% \cdot \mathrm{hr}^{-1}, n=7, p<.01\right)$ and PLA $\left(0.049 \pm 0.013 \% \cdot \mathrm{hr}^{-1}, n=10\right.$, $p<.01$ ), with no significant differences between PLA and PRO $(p=.73)$. Overnight muscle connective tissue protein FSR based on the infused and ingested $\mathrm{L}-\left[1-{ }^{13} \mathrm{C}\right]$-leucine tracer (Figure $4 \mathrm{~b}$ ) were higher in EX+PRO $\left(0.10 \pm 0.023 \% \cdot \mathrm{hr}^{-1}, n=9\right)$ when compared with PRO $\left(0.067 \pm 0.019 \% \cdot \mathrm{hr}^{-1}, n=7, p<.01\right)$ and PLA $(0.047 \pm$ $0.015 \% \cdot \mathrm{hr}^{-1}, n=10, p<.01$ ), with no significant differences between PLA and PRO $(p=.13)$. Muscle connective tissue protein-bound $\mathrm{L}-\left[1-{ }^{13} \mathrm{C}\right]$-phenylalanine enrichments (Figure 5), derived from the ingested protein, were substantially higher in EX+PRO $(0.054 \pm 0.009$ mole percent excess, $n=9)$ when compared with PRO $(0.036 \pm 0.013$ mole percent excess, $n=7 ; p<.01)$.

\section{Discussion}

In the present study, we demonstrate that presleep casein protein ingestion does not increase overnight muscle connective tissue protein synthesis rates in comparison with placebo ingestion in healthy older men. However, a bout of resistance-type exercise combined with presleep casein protein ingestion potently increases overnight muscle connective tissue protein synthesis rates. With the use of intrinsically-labeled casein protein, we demonstrate that dietary protein-derived amino acids are utilized for de novo muscle connective tissue protein synthesis at rest and to a greater extent during recovery from resistance-type exercise.

The postprandial rise in plasma amino acid concentrations, and leucine in particular, is a key factor for driving the increase in myofibrillar protein synthesis rates (Dreyer et al., 2008; Holwerda et al., 2019b). Here, protein ingestion rapidly increased plasma 


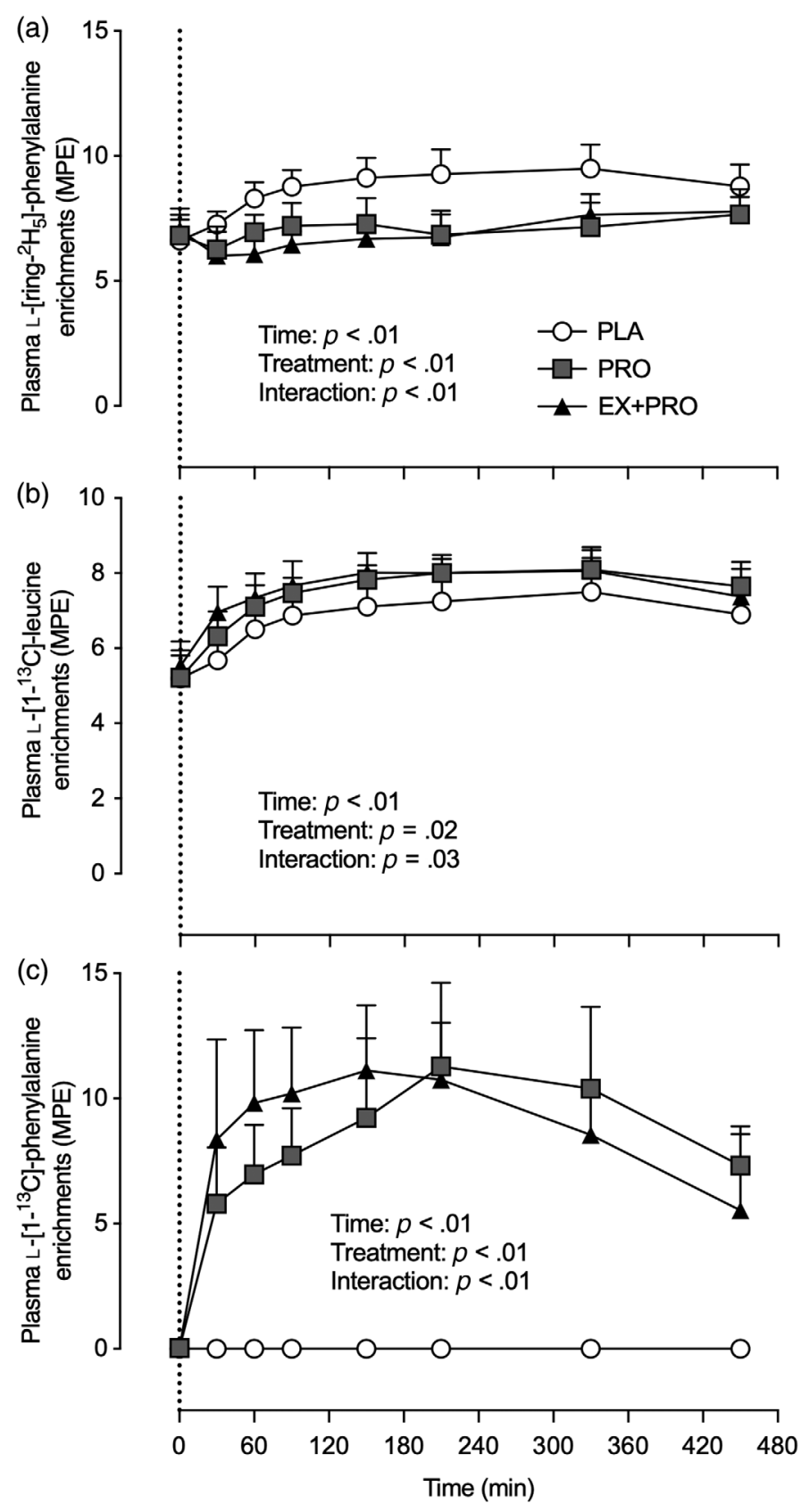

Figure 3 - (a) Overnight plasma L- $\left[\right.$ ring $\left._{-}{ }^{2} \mathrm{H}_{5}\right]-$ phenylalanine, (b) L$\left[1-{ }^{13} \mathrm{C}\right]$-leucine, and (c) $\mathrm{L}-\left[1-{ }^{13} \mathrm{C}\right]$-phenylalanine enrichments in MPE. The dotted line represents the ingestion of the presleep protein. Values represent mean $\pm S D$. Data were analyzed with a two-way repeatedmeasures (within-subject factor: time; between-subject factor: treatment) ANOVA. L- $\left[\right.$ ring $\left._{-}{ }^{2} \mathrm{H}_{5}\right]-$ phenylalanine enrichments: time effect, $p<.01$; treatment effect, $p<.01$; Time $\times$ Treatment effect, $p<.01$. $\mathrm{L}-\left[1-{ }^{13} \mathrm{C}\right]$-leucine enrichments: time effect, $p<.01$; treatment effect, $p=.02$; Time $\times$ Treatment effect, $\quad p=.03 . \quad \mathrm{L}-\left[1-{ }^{13} \mathrm{C}\right]$-phenylalanine enrichments: time effect, $p<.01$; treatment effect, $p<.01$; Time $\times$ Treatment effect, $p<.01$. PLA $=$ presleep placebo $(0 \mathrm{~g}$ protein $)$ ingestion without prior exercise; $\mathrm{PRO}=$ presleep protein $(40 \mathrm{~g}$ casein $)$ ingestion without prior exercise; $\mathrm{EX}+\mathrm{PRO}=$ presleep protein $(40 \mathrm{~g}$ casein) ingestion with prior resistance-type exercise; $\mathrm{MPE}=$ mole percent excess; ANOVA $=$ analysis of variance. insulin (Supplemental Figure 1B) and amino acid concentrations (Figure 2). The postprandial rise in plasma amino acid availability was attributed to the appearance of dietary protein-derived amino acids in the circulation, as evidenced by the rapid postprandial rise in plasma phenylalanine concentrations (Figure 2a) combined with the rise in $\mathrm{L}-\left[1-{ }^{13} \mathrm{C}\right]$-phenylalanine enrichments (Figure $3 \mathrm{c}$ ). Following protein ingestion, plasma leucine reached peak concentrations greater than $250 \mu \mathrm{mol} / \mathrm{L}$. Several studies have demonstrated that peak postprandial plasma leucine concentrations greater than $\sim 200 \mu \mathrm{mol} / \mathrm{L}$ stimulate a $30-100 \%$ increase in myofibrillar protein synthesis rates (Burd et al., 2015; Churchward-Venne et al., 2015; Holwerda et al., 2019a; Kouw et al., 2015). In agreement, we previously showed that $40 \mathrm{~g}$ casein protein ingested prior to sleep is properly digested and absorbed, resulting in ample leucine and amino acid availability to stimulate and support an increase in overnight myofibrillar protein synthesis rates in healthy older men (Holwerda et al., 2016; Kouw et al., 2017).

Holm et al. (2017) recently demonstrated that the ingestion of $\sim 18 \mathrm{~g}$ whey protein further increased postexercise muscle connective tissue protein synthesis rates when compared with the ingestion of carbohydrate during the late postprandial period (i.e., between 3 and $5 \mathrm{hr}$ after protein ingestion). Based on this finding, we hypothesized that protein ingestion has a more delayed ( $>3 \mathrm{hr}$ ) impact on stimulating muscle connective tissue protein synthesis rates. However, despite ample availability of circulating leucine following presleep casein protein ingestion at rest, we did not observe greater overnight muscle connective tissue protein synthesis rates after casein protein ingestion when compared with placebo ingestion. This is the first study to show that dairy protein ingestion does not increase muscle connective tissue protein synthesis rates during $7.5 \mathrm{hr}$ of overnight sleep. Our data in the overnight setting align with previous work demonstrating that the ingestion of either a $20 \mathrm{~g}$ essential amino acid mixture (Babraj et al., 2005) or 20-38 g whey (Mikkelsen et al., 2015) does not stimulate an increase in muscle connective tissue protein synthesis in healthy older adults during the day. Overall, despite a robust postprandial increase in circulating leucine and/or other essential amino acids, dairy protein ingestion does not stimulate an increase in muscle connective tissue protein synthesis in vivo in humans.

Resistance-type exercise is the most potent anabolic stimulus for skeletal muscle tissue protein. We have recently demonstrated that a bout of resistance-type exercise increases muscle connective tissue protein synthesis rates in younger individuals (Trommelen et al., 2020). As hypothesized in the present study, a bout of resistance-type exercise combined with presleep casein protein ingestion increased postprandial muscle connective tissue protein synthesis rates by $\sim 100 \%$ during overnight recovery in older men (Figure 4a). Our data during overnight sleep extend upon previous work showing that resistance-type exercise increases postprandial muscle connective tissue protein synthesis rates in healthy older individuals during the day (Dideriksen et al., 2016; Mikkelsen et al., 2015). However, the absence of an exercise-only group precludes our ability to determine whether the observations of greater postexercise connective tissue protein synthesis rates were the result of exercise alone or facilitated by the combination with presleep casein protein ingestion. Nevertheless, our present comparisons indicate that senescent muscle retains the capacity to upregulate muscle connective tissue protein synthesis rates in response to a bout of exercise. The postexercise increase in muscle connective tissue protein synthesis rates contributes to remodeling of the extracellular matrix. While it is known that the extracellular 
(a)

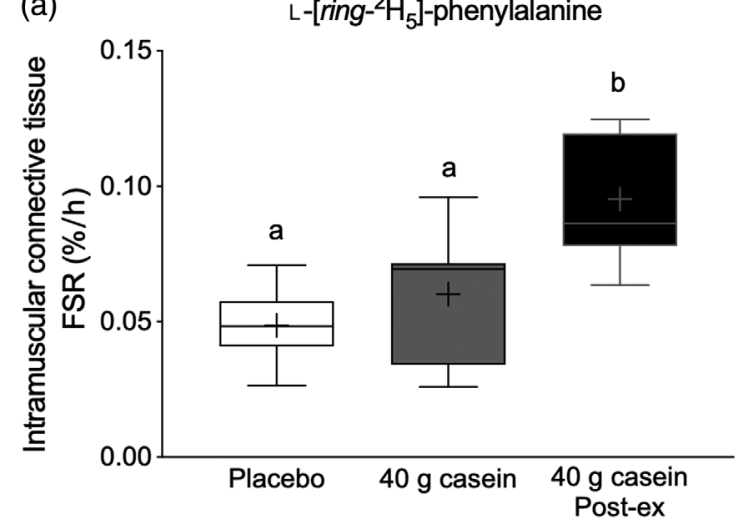

(b)

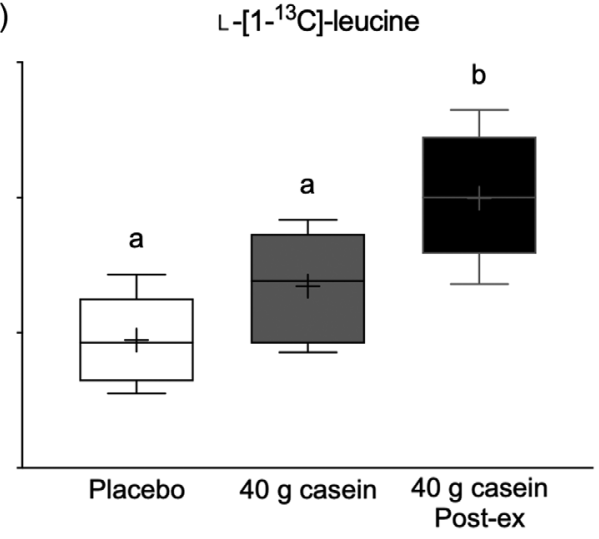

Figure 4 - Overnight muscle connective tissue protein synthetic rates (FSR in $\% / \mathrm{hr}$ ) as calculated using (a) L-[ ring- $\left.{ }^{2} \mathrm{H}_{5}\right]$-phenylalanine or (b) $\mathrm{L}-\left[1-{ }^{13} \mathrm{C}\right]$-leucine as tracer. The data are presented as box and whisker plots with the median (line), mean (cross), interquartile range (box), and minimum and maximum values (tails). Treatments without a common letter differ, $p<.05$. Data were analyzed with a one-way (between-subject factor: treatment) ANOVA. FSR based on L- $\left[\right.$ ring $\left._{-}{ }^{2} \mathrm{H}_{5}\right]$-phenylalanine: main treatment effect, $p<.001$. PLA versus EX+PRO and PRO versus EX+PRO Bonferroni-corrected post hoc comparisons, $p<.01$. FSR based on L-[1- $\left.{ }^{13} \mathrm{C}\right]$-leucine: main treatment effect, $p<.001$. PLA versus EX+PRO and PRO versus $\mathrm{EX}+\mathrm{PRO}$ Bonferroni-corrected post hoc comparisons, $p<.01$. FSR $=$ fractional synthetic rate; $\mathrm{PLA}=$ presleep placebo $(0 \mathrm{~g}$ protein) ingestion without prior exercise; $\mathrm{PRO}=$ presleep protein $(40 \mathrm{~g}$ casein $)$ ingestion without prior exercise, $\mathrm{EX}+\mathrm{PRO}=$ presleep protein $(40 \mathrm{~g}$ casein $)$ ingestion with prior resistance-type exercise; ANOVA = analysis of variance.

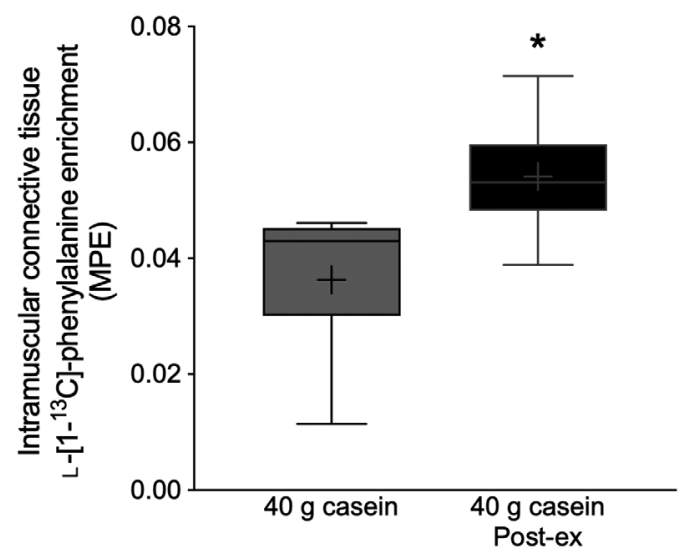

Figure 5 - Overnight L- $\left[1-{ }^{13} \mathrm{C}\right]$-phenylalanine incorporation into muscle connective tissue protein in MPE. The data are presented as box and whisker plots with the median (line), mean (cross), interquartile range (box), and minimum and maximum values (tails). The data were analyzed with an unpaired $t$ test. *Significantly different from $40 \mathrm{~g}$ casein $(p<.01)$. PRO $=$ presleep protein $(40 \mathrm{~g}$ casein) ingestion without prior exercise; $\mathrm{EX}+\mathrm{PRO}=$ presleep protein (40 g casein) ingestion with prior resistance-type exercise; $\mathrm{MPE}=$ mole percent excess.

matrix transfers force from contracting muscle tissue to tendons and bones, the functional impact of enhanced remodeling remains unclear. It could be speculated that enhanced postexercise extracellular matrix remodeling may be an important adaptation to facilitate the gains in muscle mass and/or maximal strength that occur following more prolonged resistance-type exercise training. In support, recent work demonstrates that enhanced extracellular matrix remodeling is associated with increases in muscle mass and strength in overloaded rodent plantaris muscle (Stantzou et al., 2020). Further exploration is required to determine whether the association between enhanced extracellular matrix remodeling and increases in muscle mass and strength following resistance-type exercise training in humans is causal.
By applying specifically produced highly $\mathrm{L}-\left[1-{ }^{13} \mathrm{C}\right]$-phenylalanine-enriched ( $>35$ mole percent excess) casein protein, we were able to directly assess the incorporation of dietary protein-derived amino acids into muscle connective tissue protein. Here, we demonstrate for the first time that dietary protein-derived amino acids are incorporated into de novo muscle connective tissue protein in older adults (Figure 5). Furthermore, we show that resistance-type exercise performed earlier in the evening allows more of the dietary protein-derived amino acids ( $\sim 50 \%$ more vs. PRO) to be utilized for de novo muscle connective tissue protein synthesis during overnight recovery. The present findings align with our recent work demonstrating that dietary protein-derived amino acids are incorporated into de novo muscle connective tissue protein at rest and, to a further extent, during postexercise recovery in younger individuals (Trommelen et al., 2020). Altogether, these data reinforce our findings that resistance-type exercise promotes the remodeling of muscle connective tissue and illustrate the potential role of dietary protein to support postexercise skeletal muscle tissue adaptation in older individuals.

As we did not identify any stimulatory properties of presleep casein ingestion on muscle connective tissue protein synthesis rates at rest and during recovery from a single bout of exercise, we can only speculate whether muscle connective tissue remodeling is unresponsive to protein ingestion. Alternatively, it could be speculated that muscle connective tissue is less responsive to essential amino acids and protein sources (i.e., whey and casein) that have previously been applied (Babraj et al., 2005; Dideriksen et al., 2016, 2011; Holm et al., 2010; Mikkelsen et al., 2015). Connective tissue proteins contain high concentrations of proline (12\%) and glycine (25\%) relative to other proteins within skeletal muscle (Eastoe, 1955). Casein protein contains relatively little proline (6.5\%) and glycine (2\%) and may, therefore, provide insufficient amounts of proline and/or glycine to support a postprandial or postexercise increase in muscle connective tissue protein synthesis rate (Trommelen et al., 2020). As such, the ingestion of dietary protein that contains more glycine and/or proline may better facilitate an increase in muscle connective tissue protein synthesis rates. In particular, collagen hydrolysate and gelatin contain 
approximately $12 \%$ and $26 \%$ of proline and glycine, respectively (Skov et al., 2019). Recently, Shaw et al. (2017) demonstrated that human serum collected after gelatin ingestion promotes greater collagen synthesis when exposed to engineered tissue constructs in an ex vivo setting. However, whether the ingestion of gelatin or collagen hydrolysate promotes greater muscle connective tissue protein synthesis rates in vivo in humans remains to be determined.

In conclusion, presleep casein protein ingestion does not increase overnight muscle connective tissue protein synthesis rates in healthy older men. Resistance-type exercise plus presleep casein protein ingestion increases overnight muscle connective tissue protein synthesis rates. Dietary protein-derived amino acids are utilized as precursors to support de novo muscle connective tissue protein synthesis at rest and, to a greater extent, during overnight recovery from a bout of resistance-type exercise.

\section{Acknowledgments}

A.M. Holwerda, J. Trommelen, L.B. Verdijk, and L.J.C. van Loon designed the experiment; A.M. Holwerda, J. Trommelen, and I.W.K. Kouw conducted the research; A.M. Holwerda, J.M. Senden, J.P.B. Goessens, J. van Kranenburg, and A.P. Gijsen analyzed tissue samples; A.M. Holwerda performed the statistical analysis; A.M. Holwerda, J. Trommelen, and L.J.C. van Loon analyzed the data; and A.M. Holwerda and L.J.C. van Loon wrote the paper and hold primary responsibility for final content. All authors read and approved the final manuscript. The project was funded by TI Food and Nutrition, a public-private partnership on precompetitive research in food and nutrition. The researchers are responsible for the study design, data collection and analysis, decision to publish, and preparation of the manuscript. The industrial partners have contributed to the project through regular discussion. I.W.K. Kouw, J. Trommelen, L.B. Verdijk, and L.J.C. van Loon have received speaker's fees, research grants, consulting fees, or a combination of these from Friesland Campina, Nutricia Research, and PepsiCo. None of the other authors have any conflicts of interest, financial or otherwise, to disclose.

\section{References}

Alnaqeeb, M.A., Zaid, N.S.A., \& Goldspink, G. (1984). Connective tissue changes and physical properties of developing and ageing skeletal muscle. Journal of Anatomy, 139(4), 677-689. PubMed ID: 6526719

American Diabetes Association. (2004). Follow-up report on the diagnosis of diabetes mellitus. Diabetes Spectrum, 17(1), 51-59. doi:10.2337/ diaspect.17.1.51

Azizi, E., Deslauriers, A.R., Holt, N.C., \& Eaton, C.E. (2017). Resistance to radial expansion limits muscle strain and work. Biomechanics and Modeling in Mechanobiology, 16(5), 1633-1643. PubMed ID: 28432448 doi:10.1007/s10237-017-0909-3

Babraj, J.A., Cuthbertson, D.J.R., Smith, K., Langberg, H., Miller, B., Krogsgaard, M.R., ... Rennie, M.J. (2005). Collagen synthesis in human musculoskeletal tissues and skin. American Journal of Physiology-Endocrinology and Metabolism, 289(5), E864-E869. PubMed ID: 15972270 doi:10.1152/ajpendo.00243.2005

Baumgartner, R.N., Koehler, K.M., Gallagher, D., Romero, L., Heymsfield, S.B., Ross, R.R., ... Lindeman, R.D. (1998). Epidemiology of sarcopenia among the elderly in New Mexico. American Journal of Epidemiology, 147(8), 755-763. PubMed ID: 9554417 doi:10.1093/ oxfordjournals.aje.a009520
Bergström, J., \& Hultman, E. (1967). A study of the glycogen metabolism during exercise in man. Scandinavian Journal of Clinical and Laboratory Investigation, 19(3), 218-228. PubMed ID: 6048626 doi:10.3109/00365516709090629

Burd, N.A., Gorissen, S.H., van Vliet, S., Snijders, T., \& van Loon, L.J. (2015). Differences in postprandial protein handling after beef compared with milk ingestion during postexercise recovery: A randomized controlled trial. The American Journal of Clinical Nutrition, 102(4), 828-836. PubMed ID: 26354539 doi:10.3945/ajen.114. 103184

Churchward-Venne, T.A., Snijders, T., Linkens, A.M., Hamer, H.M., van Kranenburg, J., \& van Loon, L.J. (2015). Ingestion of casein in a milk matrix modulates dietary protein digestion and absorption kinetics but does not modulate postprandial muscle protein synthesis in older men. The Journal of Nutrition, 145(7), 1438-1445. PubMed ID: 26019248 doi:10.3945/jn.115.213710

Cuthbertson, D.J., Babraj, J., Smith, K., Wilkes, E., Fedele, M.J., Esser, K., \& Rennie, M. (2006). Anabolic signaling and protein synthesis in human skeletal muscle after dynamic shortening or lengthening exercise. American Journal of Physiology-Endocrinology and Metabolism, 290(4), E731-E738. PubMed ID: 16263770 doi:10. 1152/ajpendo.00415.2005

Dideriksen, K., Reitelseder, S., Malmgaard-Clausen, N.M., Bechshoeft, R., Petersen, R.K., Mikkelsen, U.R., \& Holm, L. (2016). No effect of anti-inflammatory medication on postprandial and postexercise muscle protein synthesis in elderly men with slightly elevated systemic inflammation. Experimental Gerontology, 83, 120-129. PubMed ID: 27497779 doi:10.1016/j.exger.2016.07.016

Dideriksen, K., Reitelseder, S., Petersen, S.G., Hjort, M., Helmark, I.C., Kjaer, M., \& Holm, L. (2011). Stimulation of muscle protein synthesis by whey and caseinate ingestion after resistance exercise in elderly individuals: Milk proteins and resistance exercise. Scandinavian Journal of Medicine \& Science in Sports, 21(6), e372-e383. PubMed ID: 21535185 doi:10.1111/j.1600-0838.2011.01318.x

Dreyer, H.C., Drummond, M.J., Pennings, B., Fujita, S., Glynn, E.L., Chinkes, D.L., ... Rasmussen, B.B. (2008). Leucine-enriched essential amino acid and carbohydrate ingestion following resistance exercise enhances mTOR signaling and protein synthesis in human muscle. American Journal of Physiology-Endocrinology and Metabolism, 294(2), E392-E400. PubMed ID: 18056791 doi:10. 1152/ajpendo.00582.2007

Eastoe, J.E. (1955). The amino acid composition of mammalian collagen and gelatin. Biochemical Journal, 61(4), 589-600. PubMed ID: 13276342 doi:10.1042/bj0610589

Haus, J.M., Carrithers, J.A., Trappe, S.W., \& Trappe, T.A. (2007). Collagen, cross-linking, and advanced glycation end products in aging human skeletal muscle. Journal of Applied Physiology, 103(6), 2068-2076. PubMed ID: 17901242 doi:10.1152/japplphysiol.00670.2007

Holm, L., Rahbek, S.K., Farup, J., Vendelbo, M.H., \& Vissing, K. (2017). Contraction mode and whey protein intake affect the synthesis rate of intramuscular connective tissue. Muscle \& Nerve, 55(1), 128-130. PubMed ID: 27603578 doi:10.1002/mus.25398

Holm, L., van Hall, G., Rose, A.J., Miller, B.F., Doessing, S., Richter, E.A., \& Kjaer, M. (2010). Contraction intensity and feeding affect collagen and myofibrillar protein synthesis rates differently in human skeletal muscle. American Journal of Physiology-Endocrinology and Metabolism, 298(2), E257-E269. PubMed ID: 19903866 doi:10. 1152/ajpendo.00609.2009

Holwerda, A.M., Kouw, I.W., Trommelen, J., Halson, S.L., Wodzig, W.K., Verdijk, L.B., \& van Loon, L.J. (2016). Physical activity performed in the evening increases the overnight muscle protein 
synthetic response to presleep protein ingestion in older men. The Journal of Nutrition, 146(7), 1307-1314. PubMed ID: 27281811 doi:10.3945/jn.116.230086

Holwerda, A.M., Paulussen, K.J.M., Overkamp, M., Goessens, J.P.B., Kramer, I.F., Wodzig, W.K.W.H., ... van Loon, L.J.C. (2019a). Dose-dependent increases in whole-body net protein balance and dietary protein-derived amino acid incorporation into myofibrillar protein during recovery from resistance exercise in older men. The Journal of Nutrition, 149(2), 221-230. PubMed ID: 30722014 doi:10.1093/jn/nxy263

Holwerda, A.M., Paulussen, K.J.M., Overkamp, M., Goessens, J.P.B., Kramer, I.-F., Wodzig, W.K.W.H., ... van Loon, L.J.C. (2019b). Leucine coingestion augments the muscle protein synthetic response to the ingestion of $15 \mathrm{~g}$ of protein following resistance exercise in older men. American Journal of Physiology-Endocrinology and Metabolism, 317(3), E473-E482. PubMed ID: 31112406 doi:10. 1152/ajpendo.00073.2019

Koopman, R., \& van Loon, L.J.C. (2009). Aging, exercise, and muscle protein metabolism. Journal of Applied Physiology, 106(6), 20402048. PubMed ID: 19131471 doi:10.1152/japplphysiol.91551. 2008

Kouw, I.W., Gorissen, S.H.M., Burd, N.A., Cermak, N.M., Gijsen, A.P., van Kranenburg, J., \& van Loon, L.J.C. (2015). Postprandial protein handling is not impaired in type 2 diabetes patients when compared with normoglycemic controls. The Journal of Clinical Endocrinology \& Metabolism, 100(8), 3103-3111. PubMed ID: 26037513 doi:10. 1210/jc.2015-1234

Kouw, I.W., Holwerda, A.M., Trommelen, J., Kramer, I.F., Bastiaanse, J., Halson, S.L., . . van Loon, L.J. (2017). Protein ingestion before sleep increases overnight muscle protein synthesis rates in healthy older men: A randomized controlled trial. The Journal of Nutrition, 147(12), 2252-2261. PubMed ID: 28855419 doi:10.3945/jn.117. 254532

Kragstrup, T.W., Kjaer, M., \& Mackey, A.L. (2011). Structural, biochemical, cellular, and functional changes in skeletal muscle extracellular matrix with aging: Skeletal muscle ECM and aging. Scandinavian Journal of Medicine \& Science in Sports, 21(6), 749-757. PubMed ID: 22092924 doi:10.1111/j.1600-0838.2011. 01377.x

Mayhew, J.L., Prinster, J.L., Ware, J.S., Zimmer, D.L., Arabas, J.R., \& Bemben, M.G. (1995). Muscular endurance repetitions to predict bench press strength in men of different training levels. The Journal of Sports Medicine and Physical Fitness, 35(2), 108-113. PubMed ID: 7500624

Mikkelsen, U.R., Dideriksen, K., Andersen, M.B., Boesen, A., MalmgaardClausen, N.M., Sørensen, I.J., . . . Holm, L. (2015). Preserved skeletal muscle protein anabolic response to acute exercise and protein intake in well-treated rheumatoid arthritis patients. Arthritis Research \& Therapy, 17(1), 271. PubMed ID: 26407995 doi:10.1186/s13075015-0758-3

Mitchell, W.K., Williams, J., Atherton, P., Larvin, M., Lund, J., \& Narici, M. (2012). Sarcopenia, dynapenia, and the impact of advancing age on human skeletal muscle size and strength; a quantitative review. Frontiers in Physiology, 3, 260. PubMed ID: 22934016 doi:10.3389/ fphys.2012.00260

Moore, D.R., Phillips, S.M., Babraj, J.A., Smith, K., \& Rennie, M.J. (2005). Myofibrillar and collagen protein synthesis in human skeletal muscle in young men after maximal shortening and lengthening contractions. American Journal of Physiology-Endocrinology and Metabolism, 288(6), E1153-E1159. PubMed ID: 15572656 doi:10. 1152/ajpendo.00387.2004
Pennings, B., Boirie, Y., Senden, J.M., Gijsen, A.P., Kuipers, H., \& van Loon, L.J. (2011a). Whey protein stimulates postprandial muscle protein accretion more effectively than do casein and casein hydrolysate in older men. The American Journal of Clinical Nutrition, 93(5), 997-1005. PubMed ID: 21367943 doi:10.3945/ajen.110. 008102

Pennings, B., Koopman, R., Beelen, M., Senden, J.M., Saris, W.H., \& van Loon, L.J. (2011b). Exercising before protein intake allows for greater use of dietary protein-derived amino acids for de novo muscle protein synthesis in both young and elderly men. The American Journal of Clinical Nutrition, 93(2), 322-331. PubMed ID: 21084649 doi:10.3945/ajen.2010.29649

Ramaswamy, K.S., Palmer, M.L., van der Meulen, J.H., Renoux, A., Kostrominova, T.Y., Michele, D.E., \& Faulkner, J.A. (2011). Lateral transmission of force is impaired in skeletal muscles of dystrophic mice and very old rats: Lateral transmission of force in skeletal muscles of mice and rats. The Journal of Physiology, 589(5), 1195-1208. PubMed ID: 21224224 doi:10.1113/jphysiol. 2010.201921

Shaw, G., Lee-Barthel, A., Ross, M.L., Wang, B., \& Baar, K. (2017). Vitamin C-enriched gelatin supplementation before intermittent activity augments collagen synthesis. The American Journal of Clinical Nutrition, 105(1), 136-143. PubMed ID: 27852613 doi:10. 3945/ajen.116.138594

Skov, K., Oxfeldt, M., Thøgersen, R., Hansen, M., \& Bertram, H.C. (2019). Enzymatic hydrolysis of a collagen hydrolysate enhances postprandial absorption rate-A randomized controlled trial. Nutrients, 11(5), 1064. PubMed ID: 31086034 doi:10.3390/ nu11051064

Snijders, T., Trommelen, J., Kouw, I.W., Holwerda, A.M., Verdijk, L.B., \& van Loon, L.J.C. (2019). The impact of pre-sleep protein ingestion on the skeletal muscle adaptive response to exercise in humans: An update. Frontiers in Nutrition, 6, 17. PubMed ID: 30895177 doi:10. 3389/fnut.2019.00017

Stantzou, A., Relizani, K., Morales-Gonzalez, S., Gallen, C., Grassin, A., Ferry, A., ... Amthor, H. (2020). Extracellular matrix remodelling is associated with muscle force increase in overloaded mouse plantaris muscle. Neuropathology and Applied Neurobiology. Advance online publication. PubMed ID: 32772401 doi:10.1111/ nan. 12655

Trommelen, J., Betz, M.W., \& van Loon, L.J.C. (2019). The muscle protein synthetic response to meal ingestion following resistance-type exercise. Sports Medicine, 49(2), 185-197. PubMed ID: 30659499 doi:10.1007/s40279-019-01053-5

Trommelen, J., Holwerda, A.M., Kouw, I.W., Langer, H., Halson, S.L., Rollo, I., . . V Van Loon, L.J.C. (2016). Resistance exercise augments postprandial overnight muscle protein synthesis rates. Medicine \& Science in Sports \& Exercise, 48(12), 2517-2525. PubMed ID: 27643743 doi:10.1249/MSS.0000000000001045

Trommelen, J., Holwerda, A.M., Senden, J.M., Goessens, J.P.B., Van Kranenburg, J., Gijsen, A.P., . . Van Loon, L.J.C. (2020). Casein ingestion does not increase muscle connective tissue protein synthesis rates. Medicine \& Science in Sports \& Exercise, 52(9), 1983-1991. PubMed ID: 32195768 doi:10.1249/MSS.00000000 00002337

Trommelen, J., Kouw, I.W., Holwerda, A.M., Snijders, T., Halson, S.L., Rollo, I., ... van Loon, L.J.C. (2018). Presleep dietary proteinderived amino acids are incorporated in myofibrillar protein during postexercise overnight recovery. American Journal of PhysiologyEndocrinology and Metabolism, 314(5), E457-E467. PubMed ID: 28536184 doi:10.1152/ajpendo.00273.2016 
Volpi, E., Kobayashi, H., Sheffield-Moore, M., Mittendorfer, B., \& Wolfe, R.R. (2003). Essential amino acids are primarily responsible for the amino acid stimulation of muscle protein anabolism in healthy elderly adults. The American Journal of Clinical Nutrition, 78(2), 250-258. PubMed ID: 12885705 doi:10.1093/ajen/78.2.250

Wood, L.K., Kayupov, E., Gumucio, J.P., Mendias, C.L., Claflin, D.R., \& Brooks, S.V. (2014). Intrinsic stiffness of extracellular matrix increases with age in skeletal muscles of mice. Journal of Applied Physiology, 117(4), 363-369. PubMed ID: 24994884 doi:10.1152/ japplphysiol.00256.2014

Zhang, C., \& Gao, Y. (2014). Effects of aging on the lateral transmission of force in rat skeletal muscle. Journal of Biomechanics, 47(5), 944-948. PubMed ID: 24507947 doi:10.1016/j.jbiomech.2014. 01.026 